\title{
PERFORMANCE OF SOYBEAN CULTIVARS AT DIFFERENT DOSES OF BASE FERTILIZATION ON Brachiaria decumbens STRAW
}

\author{
DESEMPENHO DE CULTIVARES DE SOJA EM DIFERENTES DOSES DE \\ ADUBAÇÃO DE BASE SOBRE PALHADA DE Brachiaria decumbens
}

\section{Francisco Eduardo TORRES1; Ademilson da Silva LOURENÇÃO²; Paulo Eduardo TEODORO ${ }^{3}$; Wanderléia Rodrigues dos SANTOS ${ }^{4}$; Larissa Pereira RIBEIRO ${ }^{4}$; Carlos Henrique Martins de SOUZA ${ }^{6}$; Caio Cezar Guedes CORRÊEA ${ }^{3}$; Miriam Ferreira LIMA ${ }^{3}$}

1. Engenheiro Agrônomo, Dr. em Fitotecnia, Docente Adjunto do Curso de Agronomia e do Programa de Pós-graduação em Produção Vegetal da Universidade Estadual de Mato Grosso do Sul (UEMS), Aquidauana, MS, Brasil; 2. Engenheiro Agrônomo, UEMS, Aquidauana, MS, Brasil; 3. Discentes do Programa de Pós-Graduação stricto sensu em Agronomia - área de concentração: Produção Vegetal, da UEMS, Aquidauana, MS, Brasil. eduteodoro@ hotmail.com; 4. Aluna do curso de Agronomia da UEMS, Aquidauana, MS, Brasil. 5. Professora, M. Sc., curso de Engenharia Florestal e Zootecnia - UEMS, Aquidauana, MS, Brasil.

${ }^{5}$ Discente do Programa de Pós-Graduação stricto sensu em Engenharia Agrícola da Universidade Federal da Grande Dourados (UFGD), Dourados, MS, Brasil.

\begin{abstract}
The deployment of soybean under no-tillage in degraded pasture has been a trivial practice, and the efficient and rational use of fertilizers is a decisive to its economic viability factor. The objective was to evaluate the agronomic performance of six cultivars subjected to doses of basic fertilization with NPK and straw grown on Brachiaria decumbens. The experiment was conducted in the experimental area of the State University of Mato Grosso do Sul, Unit Aquidauna. The experimental design was a randomized block design in split plot design with four replications. The plots consisted of six soybean cultivars (NA 5909 RR, M SOY 7908 RR, BMX Magna RR, BRS 245 RR, SYN 3358 RR, BMX Potência RR) and the subplots of five doses of NPK (0,50,100, 200 and $\left.400 \mathrm{~kg} \mathrm{ha}^{-1}\right)$. Were evaluated plant height, first pod height, number of ramifications per plant, mass of 1000 grains and grain yield. Increased doses of fertilizer caused a linear increase in all variables in all cultivars, being recommended for degraded pastures base fertilization with $400 \mathrm{~kg}^{-1}$ of NPK. The varieties BMX Power RR 3358 and RR SYN showed higher mass of 1000 grains and consequently higher grain yield.
\end{abstract}

KEYWORDS: Crop-livestock integration. Degraded pasture. Glycine max. No-tillage.

\section{INTRODUCTION}

The main oilseed crop grown in Brazil and in the world is the soybean [Glycine $\max$ (L.) Merrill], being same source of raw material of great importance, especially to sectors of agribusiness and animal nutrition. The area planted with this oilseed in Brazil in 2013/14 was approximately 30 million hectares, with an increase of $8.6 \%$ compared to $2012 / 13$. In relation to production just over 86.2 million tons of grains was obtained, an increase of $5.9 \%$ compared with 81.5 million tones produced in the harvest 2012/13 (CONAB, 2014).

The Brazilian average productivity in 2013/14 was 2,900 $\mathrm{kg} \mathrm{ha}^{-1}$, considered high in comparison to other countries (CONAB, 2014). The average increment of $38 \mathrm{~kg} \mathrm{ha}^{-1}$ year $^{-1}$ in yield grain between $1976 / 77$ to $2013 / 14$ is related to various causes, among which stands out the cultivation of highly productive cultivars (LUDWIG et al. 2011).

The high yield potential of the cultivars is the main objective of genetic breeding and the producer has the function of allowing this to express yourself, provided with the proper environment. To define the type of base fertilizer to be adopted at the time of soybean implantation should be defined considering the inherent characteristics of each cultivar and environmental conditions, because they can interfere in the expected results, such as higher grains yield, plant height and pods insertion height appropriate for mechanized harvesting (REZENDE et al., 2004; CARVALHO et al., 2011).

The seeding density, plant population and fertilization to be performed in soybean are much discussed topics on which many studies already been published, however the interaction genotype versus environment directly affects the results, which makes it necessary new researches in order to improve the productive performance of this legume and exploit their productive potential (LUDWIG et al., 2011; RAMBO et al., 2003).

Soybean has been widely used in croplivestock integration, which consists of a very efficient alternative to maintaining productivity and recovery of Brazilian pastures (MACHADO et al., 2011). In this system, crops are implanted to make 
constant part of a system of grain production and animal production that interact and complement each other in several aspects such as management, fertility, physics and biology of the soil, thereby increasing farmer incomes and bringing social progress to the field (MACEDO, 2009).

One of the main factors that limit the productivity of a culture implanted on the integrated crop-livestock system is the nutrient management (CARVALHO et al., 2011), because usually the pastures are in some state of disrepair or in areas with degraded soils (PAULINO et al., 2012; GARCIA et al., 2014). However, there are little recommendations in the literature for the base fertilization of soybean in the crop-livestock system, justifying the present research.

Front of this context, this study aimed to evaluate the performance of six soybean cultivars at different doses of base fertilizer on straw Brachiaria decumbens Stapf. pasture degraded on Savanna/Pantanal ecotone region.

\section{MATERIAL AND METHODS}

The experiment was installed in the agricultural year 2011/2012, at experimental area of Universidade Estadual de Mato Grosso do Sul University Unit of Aquidauana (UEMS/UUA), in Aquidauana (MS), located in the Savanna/Pantanal ecotone region, comprising the coordinates $20^{\circ} 27^{\prime} \mathrm{S}$ and $55^{\circ} 40^{\prime} \mathrm{W}$ with an average elevation of $170 \mathrm{~m}$.

The soil was classified by Schiavo et al. (2011) as Ultisol sandy loam texture. Chemical analysis of the soil is showed in Table 1, and the results of granulometric analysis and soil density are showed in Table 2. The climate of the region according to classification described by KöppenGeiger is Aw (Savanna Tropical). The data rainfall and the temperature average of the experimental period are disposed in the Figure 1.

Table 1. Results of soil chemical analysis in experimental area of layer 0-0.20 m. Aquidauana, MS, 2011.

\begin{tabular}{llllllllll}
\hline $\mathrm{pH}$ & $\mathrm{P}$ & $\mathrm{O}$ & $\mathrm{Ca}$ & $\mathrm{Mg}$ & $\mathrm{K}$ & $\mathrm{Al}$ & $\mathrm{H}+\mathrm{Al}$ & $\mathrm{CEC}$ & $\mathrm{V}$ \\
\hline $\mathrm{CaCl}_{2}$ & $\mathrm{mg} \mathrm{dm}$ & $\mathrm{g} \mathrm{dm}^{-3}$ & $\ldots \ldots \ldots \ldots \ldots \ldots \ldots \ldots \ldots . . \mathrm{cmol}_{\mathrm{c}} \mathrm{dm}^{-3}$ & $\ldots \ldots \ldots \ldots \ldots \ldots \ldots \ldots \ldots . . \ldots \ldots \ldots \ldots \ldots \ldots \ldots \ldots \ldots \ldots$ & & $\%$ \\
\hline 5.74 & 3.16 & 10.91 & 1.75 & 1.00 & 0.21 & 0.00 & 1.46 & 4.42 & 66.9 \\
\hline
\end{tabular}

Phosphorus (P) - Mehlich; O.M: organic matter; CEC: cation exchange capacity.

Table 2. Results of granulometric analysis and soil density of the experimental area in the layers $0-0.10 \mathrm{~m}$, 0.10-0.20 m and 0.20-0.40 m. Aquidauana, MS, 2011.

\begin{tabular}{lllll}
\hline $\begin{array}{l}\text { Depth } \\
(\mathrm{m})\end{array}$ & \multicolumn{2}{l}{ Granulometric $(\%)$} & \multicolumn{2}{c}{$\begin{array}{l}\text { Soil density } \\
\left(\mathrm{g} \mathrm{cm}^{-3}\right)\end{array}$} \\
\cline { 2 - 5 } & Sand & Silt & Clay & 1.57 \\
$0-0.10$ & 68.31 & 16.63 & 15.06 & 1.67 \\
$0.10-0.20$ & 69.07 & 15.18 & 15.75 & 1.70 \\
$0.20-0.40$ & 69.28 & 15.15 & 15.57 & \\
\hline
\end{tabular}

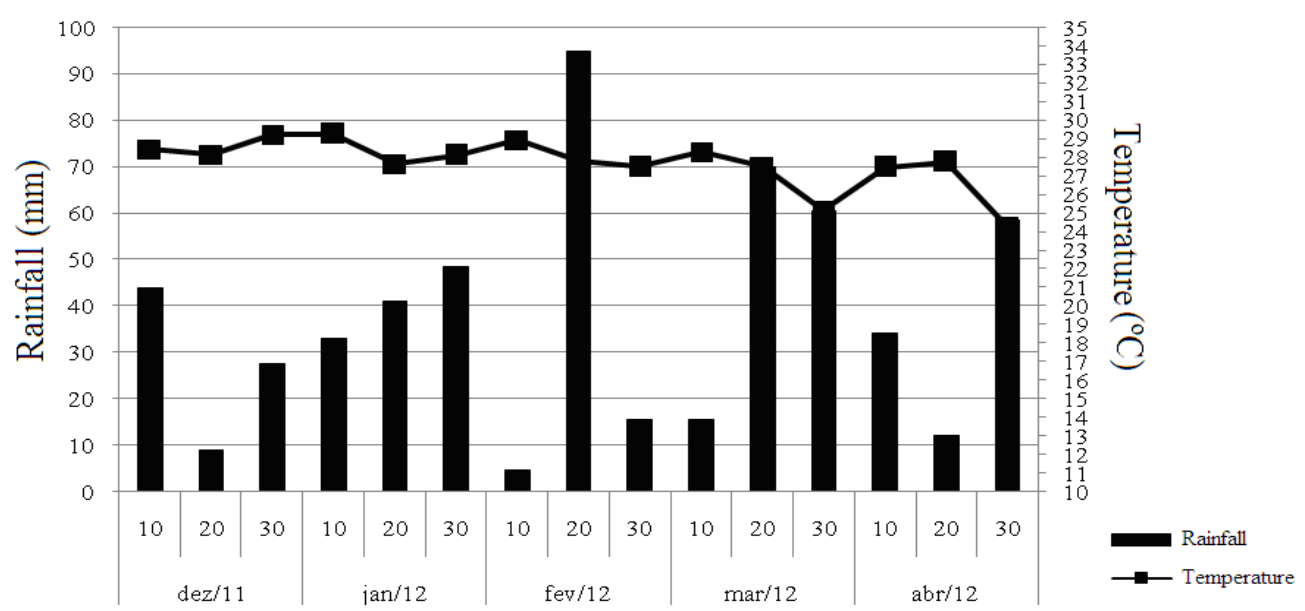

Figure 1. Rainfall (mm) and temperature $\left({ }^{\circ} \mathrm{C}\right)$ average in the year 2011/2012. 
The plots consisted of six soybean cultivars: NA 5909 RR, M SOY 7908 RR, BMX Magna RR, BRS 245 RR, SYN 3358 RR, BMX Potência RR (Table 3), and subplots for four levels of fertilization, plus the control $(0,50,100,200$ e 400 $\mathrm{kg} \mathrm{ha}^{-1}$ commercial fertilizer formula 4-20-20). Each plot had an area of $45 \mathrm{~m}^{2}(9 \times 5 \mathrm{~m})$, and each subplot was constituted by four plant rows spaced $0.45 \mathrm{~m}$ between rows and 5 meters of length with an area of $9 \mathrm{~m}^{2}(1.8 \times 5 \mathrm{~m})$. Table 3 show the cycle, growth habit and maturity group of the cultivars used in the experiment.

Table 3. Commercial name, cycle, growth habit and maturity group of the cultivars used in the experiment. Aquidauana, MS, 2011.

\begin{tabular}{llll}
\hline Commercial name & Cycle & Growth habit & Maturity group \\
\hline NA 5909 RR & Premature & Indeterminate & 5.9 \\
M SOY 7908 RR & Premature & Determinate & 7.9 \\
BMX Magna RR & Premature & Indeterminate & 6.2 \\
SYN 3358 RR & Premature & Indeterminate & 5.8 \\
BRS 245 RR & Semi-premature & Determinate & 7.3 \\
BMX Potência RR & Semi-premature & Indeterminate & 6.7 \\
\hline
\end{tabular}

The pasture (Brachiaria decumbens, cultivar Basilisck) cultivated in the experimental area was desiccated with glyphosate active ingredient at dose of $3 \mathrm{~L} \mathrm{ha}^{-1}, 14$ days before of seeding as recommended Nunes et al. (2009). The sowing was done manually at $08 / 12 / 2011$ with 20 seeds per meter, with germination rate of $80 \%$, achieving an average density of 16 per meter, corresponding to a population of 355,555 plants ha 1 .

Seed treatment was performed with Thiram® 480 TS fungicide at dose $300 \mathrm{~mL} 100 \mathrm{~kg}^{-1}$ seeds of the commercial product, Imidacloprido (Imidacloprido) insecticide at a dose $150 \mathrm{~mL} 100$ $\mathrm{kg}^{-1}$ seeds of the commercial product and at the moment of sowing the seeds were inoculated with peaty-based Bradyrhizobium japonicum inoculant at a dose of 240 grams per $100 \mathrm{~kg}$ seeds of the commercial product.

The control of Pseudoplusia includens Wal. and Anticarcia gemmatalis Hüb. was performed at 45 and 70 days after emergence (DAE) using the active ingredient Teflubenzuron at a dose of $50 \mathrm{~mL}$ $\mathrm{ha}^{-1}$ of the commercial product. Fungicide application was not performed. The weeds were controlled by hand weeding. At 80 DAE was measured the descriptors plant height $(\mathrm{PH})$ and first pod insertion height $(\mathrm{PIH})$, the assessments were done on 10 plants per plot with the aid of a tape measure.

The harvest was done manually to 115 DAE, and at this time was evaluated the descriptors: number of ramifications per plant (NR), mass of 1000 grains (MTG) and grain yield (YIE). To evaluation of number of pods and number of ramifications per plant were used 10 plants per plot, and for the evaluation of MTG and YIE, were collected plants from the two central rows of each plot using an analytical balance to determine the last two variables The grain moisture was corrected to $13 \%$ and YIE was extrapolated for $\mathrm{kg} \mathrm{ha}^{-1}$.

The variables analyzed were initially submitted to Shapiro-Wilk's test to verify the normality of residuals and Bartlett's test for homogeneity of variances. Subsequently, the data were subjected to analysis of variance by applying the F-test. The qualitative factor (cultivars) underwent comparison of means by Tukey's test and the quantitative (doses of NPK) to polynomial regression. The best fitted equation is selected according to the coefficient of determination and significance of regression coefficients, the tested waste corrected based on analysis of variance t-test. All analyzes were performed with statistical software Sisvar (FERREIRA et al., 2011).

\section{RESULTS AND DISCUSSION}

Significant effect for doses of NPK (F), cultivars (C) and the interaction of between factors for all variables measured was observed, as shown on Table 4. The coefficient of variation (CV) was under $20 \%$ indicating good accuracy of evaluations

Evaluating the AP for interaction $\mathrm{F} \times \mathrm{C}$ (Table 5) there was no statistical difference between cultivars for control (dose 0). In the dose of $50 \mathrm{~kg}$ $\mathrm{ha}^{-1}$ of NPK, the cultivar BRS 245 RR was the one with the lowest average height, differing from the 
others. For dose of $100 \mathrm{~kg} \mathrm{ha}^{-1}$ of NPK, the cultivars BMX Magna RR, SYN 3358 RR3 and BMX Potência RR were the ones that stood out and did not differ between them. As for the dose of $200 \mathrm{~kg}$ $\mathrm{ha}^{-1}$ the cultivars that obtained better averages were
BMX Potência and SYN RR 3358 RR with no differences between them. The dose of $400 \mathrm{~kg} \mathrm{ha}^{-1}$ of NPK, the cultivar with larger average height was the BMX Potência RR, differing from the others.

Table 4. F values calculated from analysis of variance of plant height (PH), pod insertion height (PIH), number of ramifications (NR), mass of 1000 grains (MTG) and yield grain (YIE) of six soybean cultivars (C) cultivated in different doses of NPK (F). Aquidauana, MS, 2012.

\begin{tabular}{ccccccc}
\hline \multirow{2}{*}{ FV } & \multicolumn{7}{c}{ Variables } \\
\cline { 2 - 6 } & G.L. & PH & PIH & NR & MTG & YIE \\
\hline F & 4 & $1412.1^{* *}$ & $257.20^{* *}$ & $481.15^{* *}$ & $3623.9^{* *}$ & $622.3^{* *}$ \\
C & 5 & $60.39^{* *}$ & $145.83^{* *}$ & $49.59^{* *}$ & $251.96^{* *}$ & $86.83^{* *}$ \\
F x C & 20 & $20.33^{* *}$ & $12.46^{* *}$ & $5.64^{* *}$ & $26.97^{* *}$ & $3.34^{* *}$ \\
\hline Error F (\%) & 72 & 46.69 & 7.6 & 8.95 & 106.57 & 1944.5 \\
\hline Error C (\%) & 18 & 3.43 & 3.42 & 4.32 & 1.05 & 7.83 \\
\hline
\end{tabular}

** Significant at $1 \%$ probability; $\mathrm{CV} \%=$ coefficient of variation in percentage; $\mathrm{FV}=$ Fonts of variation.

Table 5. Plant height $(\mathrm{PH})$ and pod insertion height $(\mathrm{PIH})$ of six soybean cultivars submitted at different doses of NPK. Aquidauana, MS, 2012.

Doses of NPK $\left(\mathrm{kg} \mathrm{ha}^{-1}\right)$

\begin{tabular}{cccccc}
\hline \multirow{2}{*}{ Cultivars } & & \multicolumn{5}{c}{ PH $(\mathrm{cm})$} \\
\cline { 3 - 6 } & 0 & 50 & 100 & 200 & 400 \\
\hline BMX Magna RR & $34.48 \mathrm{a}$ & $37.68 \mathrm{a}$ & $47.66 \mathrm{a}$ & $54.33 \mathrm{c}$ & $57.88 \mathrm{~d}$ \\
MSOY 7908 RR & $33.65 \mathrm{a}$ & $36.11 \mathrm{ab}$ & $41.60 \mathrm{c}$ & $46.67 \mathrm{~d}$ & $55.42 \mathrm{~d}$ \\
SYN 3358 RR & $32.74 \mathrm{a}$ & $35.63 \mathrm{ab}$ & $46.60 \mathrm{ab}$ & $60.80 \mathrm{ab}$ & $68.70 \mathrm{~b}$ \\
BMX Potência RR & $34.08 \mathrm{a}$ & $38.07 \mathrm{a}$ & $45.31 \mathrm{ab}$ & $63.21 \mathrm{a}$ & $72.41 \mathrm{a}$ \\
ND 5909 RR & $34.14 \mathrm{a}$ & $37.64 \mathrm{a}$ & $44.28 \mathrm{bc}$ & $52.77 \mathrm{c}$ & $56.98 \mathrm{~d}$ \\
BRS 245 RR & $33.57 \mathrm{a}$ & $34.01 \mathrm{~b}$ & $43.69 \mathrm{bc}$ & $57.91 \mathrm{~b}$ & $62.72 \mathrm{~b}$ \\
\hline & & & PIH $(\mathrm{cm})$ & & \\
\hline BMX Magna RR & $8.25 \mathrm{a}$ & $8.11 \mathrm{a}$ & $7.60 \mathrm{~b}$ & $8.68 \mathrm{a}$ & $9.42 \mathrm{a}$ \\
MSOY 7908 RR & $5.51 \mathrm{c}$ & $6.57 \mathrm{~b}$ & $6.56 \mathrm{c}$ & $7.44 \mathrm{c}$ & $7.54 \mathrm{c}$ \\
SYN 3358 RR & $5.76 \mathrm{c}$ & $6.60 \mathrm{~b}$ & $7.52 \mathrm{~b}$ & $8.23 \mathrm{~b}$ & $8.45 \mathrm{~b}$ \\
BMX Potência RR & $6.54 \mathrm{~b}$ & $6.21 \mathrm{~b}$ & $7.54 \mathrm{~b}$ & $7.61 \mathrm{c}$ & $9.00 \mathrm{a}$ \\
ND 5909 RR & $6.55 \mathrm{~b}$ & $6.44 \mathrm{~b}$ & $7.56 \mathrm{~b}$ & $7.55 \mathrm{c}$ & $8.28 \mathrm{~b}$ \\
BRS 245 RR & $6.75 \mathrm{~b}$ & $8.16 \mathrm{a}$ & $8.88 \mathrm{a}$ & $9.15 \mathrm{a}$ & $9.52 \mathrm{a}$ \\
\hline
\end{tabular}

Averages followed by the same letter in rows do not differ by Tukey's test at 5\% probability.

Analyzing the PIH as function of the interaction of variables $\mathrm{F} \times \mathrm{C}$, been found for control (dose 0) that the cultivar BMX Magna RR showed higher average PIH, differing from the other cultivars, already in the dose of $50 \mathrm{~kg} \mathrm{ha}^{-1}$ of NPK the cultivars BMX Magna RR and BRS 245 RR 
were the ones that stood out, differing significantly from the others. At a dose of $200 \mathrm{~kg} \mathrm{ha}^{-1}$ of NPK, the cultivars BMX Magna RR and BRS 245 RR showed the highest values of PIH, did not differing among them. At a dose of $400 \mathrm{~kg} \mathrm{ha}^{-1}$ of NPK, the cultivars BRS 245 RR, BMX Magna RR and BMX Potência RR were statistically different, highlighting from the others.

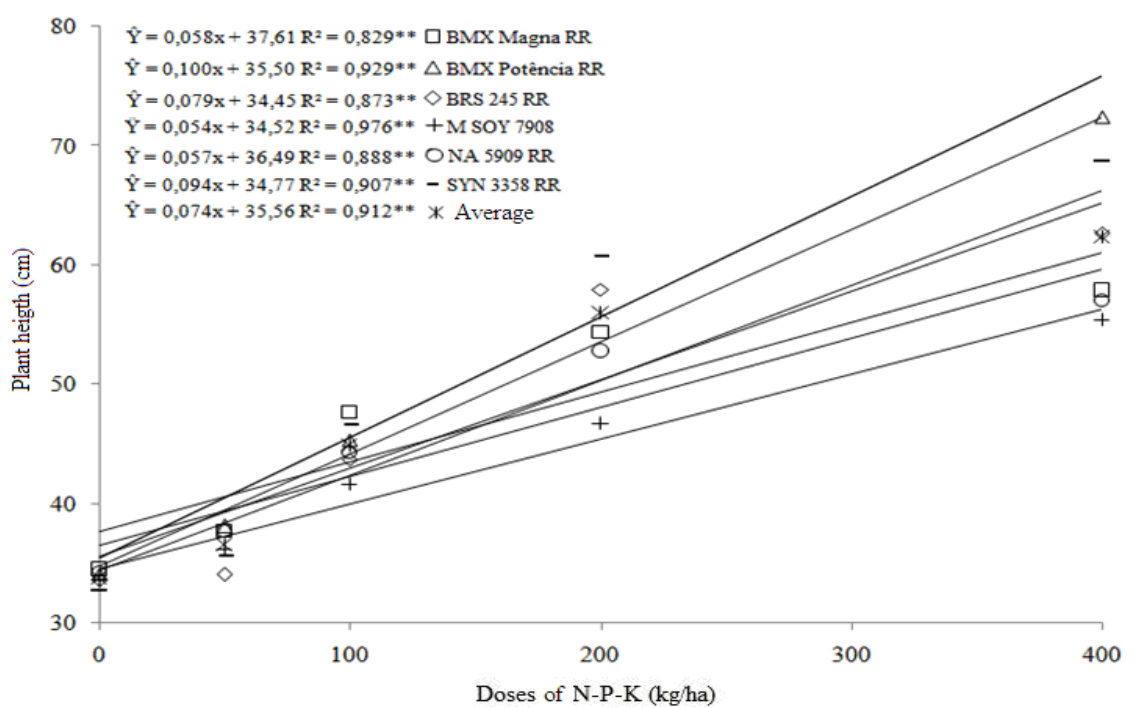

Figure 2. Plant height $(\mathrm{PH})$ of six soybean cultivars as function of different doses of base NPK. Aquidauana, MS, 2012.

Larger plants can have more branching and armpits where the pods will develop, increasing YIE. On the other hand, there are more susceptible to lodging, which can result in losses at harvest. Mauad et al., (2010) recommended a minimum height of $60 \mathrm{~cm}$ to any reduction in grain losses in the harvesting operation. Based on this variable, it is recommended fertilization with 200 or $400 \mathrm{~kg} \mathrm{ha}^{-1}$

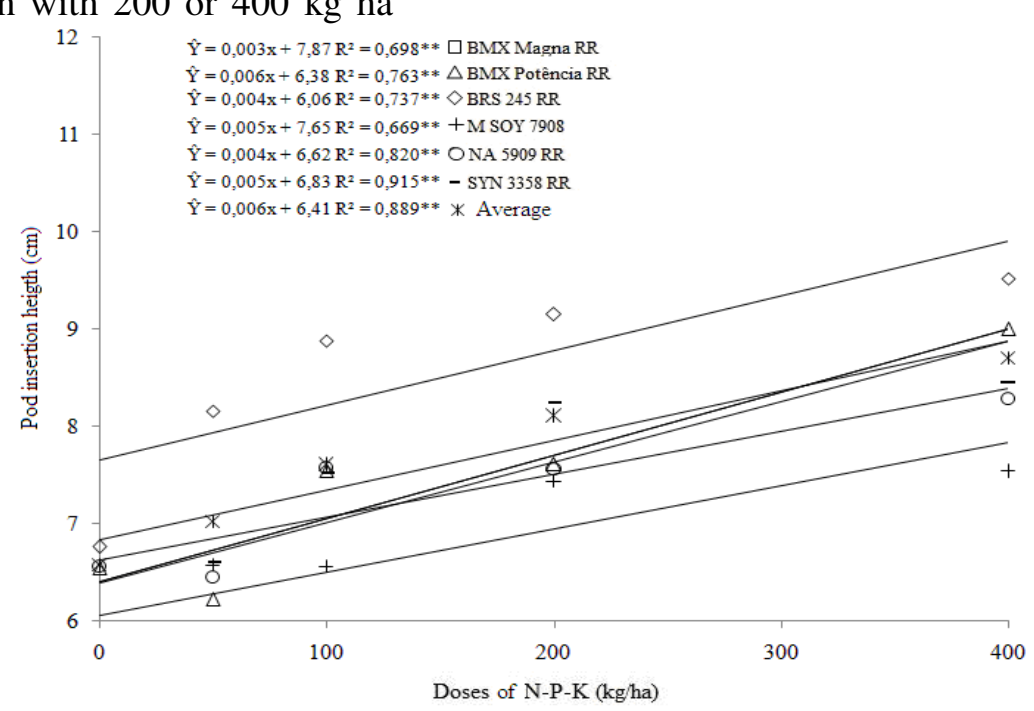

Figure 3. Pod insertion height (PIH) of six soybean cultivars as function of different doses of NPK. of NPK to cultivars BMX Potência RR and SYN $3358 \mathrm{RR}$ and $400 \mathrm{~kg} \mathrm{ha}^{-1}$ of NPK to cultivar BRS $245 \mathrm{RR}$.

There was a linear increase in variable PIH relative to doses of NPK, reaching greater height with $400 \mathrm{~kg} \mathrm{ha}^{-1}$ in all cultivars, corroborating the results obtained by Carvalho et al. (2011) (Figure 3).

\footnotetext{
Aquidauana, MS, 2012.
} 
According to Marcos Filho (1986), the PIH is an important feature, because as from $12 \mathrm{~cm}$ is possible to minimize the losses in the mechanical harvesting, what allows to infer that at no dose of NPK, any cultivar showed the height required for this type of harvest.

Araújo et al. (2005) argue that the variation in the dose of NPK did not influence the PIH variable in soybean, inherent characteristic to cultivar, contradicting the results of this work. The PIH were influenced by doses of NPK probably due to the amount of phosphorus present in the soil, relatively low for the soybean (TAIZ; ZEIGER, 2013).
Analyzing the NR of each cultivar in relation to $\mathrm{F} \times \mathrm{C}$ interaction was observed that for the control (dose 0), there was no statistical difference among cultivars (Table 6). For the dose of $50 \mathrm{~kg} \mathrm{ha}^{-1}$ the cultivars BMX Potência RR, BRS 245 RR and SYN 3358 RR have excelled, not differing among themselves, while the latter two did not differ statistically among others. For the dose of 100, 200 and $400 \mathrm{~kg} \mathrm{ha}^{-1}$ the cultivars BMX Potência RR, BRS 245 RR and SYN 3358 RR showed higher NR, having no difference among themselves, but differing significantly from the other cultivars.

Table 6. Number of ramifications per plant (NR) of six soybean cultivars submitted at different doses of NPK. Aquidauana, MS, 2012.

\begin{tabular}{cccccc}
\hline \multicolumn{7}{c}{ Doses of NPK $\left(\mathrm{kg} \mathrm{ha}^{-1}\right)$} \\
\cline { 3 - 6 } Cultivars & 0 & 50 & 100 & 200 & 00 \\
\hline BMX Magna RR & $7.00 \mathrm{a}$ & $7.12 \mathrm{~b}$ & $7.92 \mathrm{~b}$ & $9.37 \mathrm{~b}$ & $10.57 \mathrm{~b}$ \\
MSOY 7908 RR & $6.87 \mathrm{a}$ & $7.47 \mathrm{~b}$ & $8.27 \mathrm{~b}$ & $8.50 \mathrm{c}$ & $10.02 \mathrm{~b}$ \\
SYN 3358 RR & $6.85 \mathrm{a}$ & $7.80 \mathrm{ab}$ & $9.40 \mathrm{a}$ & $10.62 \mathrm{a}$ & $12.17 \mathrm{a}$ \\
BMX Potência RR & $7.27 \mathrm{a}$ & $8.37 \mathrm{a}$ & $9.77 \mathrm{a}$ & $10.75 \mathrm{a}$ & $12.50 \mathrm{a}$ \\
ND 5909 RR & $6.87 \mathrm{a}$ & $7.57 \mathrm{~b}$ & $8.57 \mathrm{~b}$ & $9.65 \mathrm{~b}$ & $10.57 \mathrm{~b}$ \\
BRS 245 RR & $6.67 \mathrm{a}$ & $7.82 \mathrm{ab}$ & $9.80 \mathrm{a}$ & $10.62 \mathrm{a}$ & $11.77 \mathrm{a}$ \\
\hline
\end{tabular}

Averages followed by the same letter in rows do not differ by Tukey's test at 5\% probability.

The NR is determined during the late vegetative and reproductive stages initials. Proper plant nutrition is fundamental to the development of reproductive buds, storage photoassimilates, decreased abortion of flowers and pods (TAIZ; ZEIGER, 2013). Therefore, it is recommended to base fertilization $400 \mathrm{~kg} \mathrm{ha}^{-1}$ of NPK for all cultivars (Figure 4).

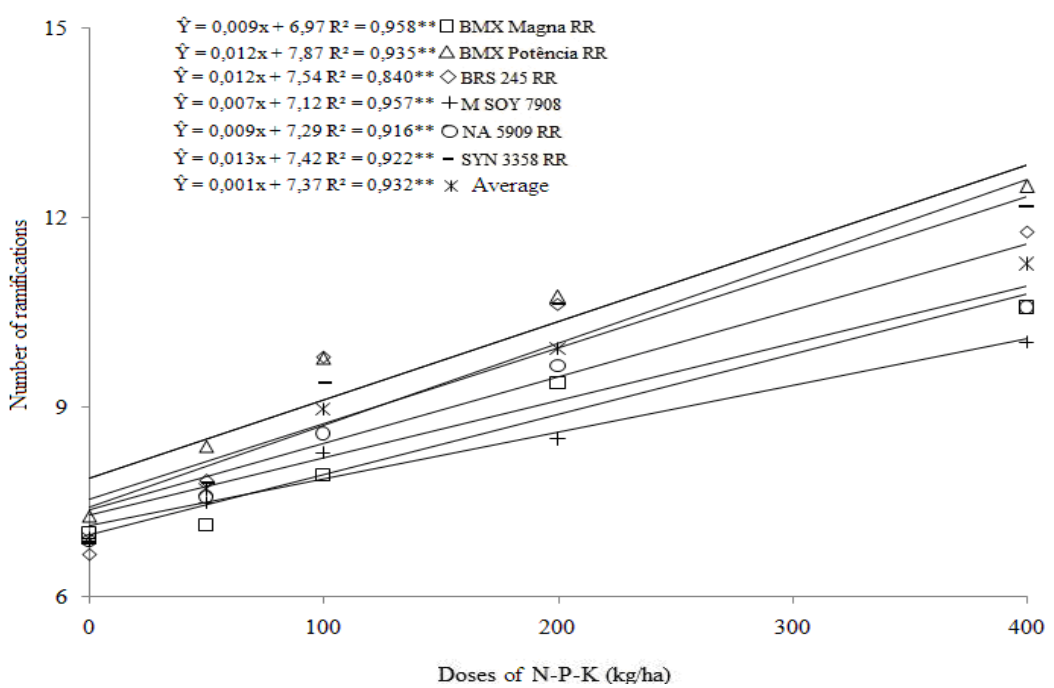

Figure 4. Number of ramifications (NR) of six soybean cultivars as function of different doses of NPK. Aquidauana, MS, 2012. 
Independent of level of fertilization, the cultivars SYN 3358 RR and BMX Potência RR, that obtained higher NR, showed higher MTG and, consequently, higher YIE (Table 7). According to Taiz and Zeiger (2013) and Navarro Junior et al.
(2002) this occurred possibly because how much greater NR, greater will be the quantity of trifoliate leaves, resulting in high photosynthetic area, that can result in greater YIE.

Table 7. Mass of thousand grains (MTG) and yield grains (YIE) of six soybean cultivars submitted at different doses of NPK. Aquidauana, MS, 2012.

\begin{tabular}{cccccc}
\hline \multicolumn{5}{c}{ Doses of NPK $\left(\mathrm{kg} \mathrm{ha}^{-1}\right)$} \\
\hline Cultivars & 0 & 50 & 100 & 200 & 400 \\
\cline { 2 - 6 } BMX Magna RR & $87.27 \mathrm{bc}$ & $96.61 \mathrm{~b}$ & $104.01 \mathrm{e}$ & $107.30 \mathrm{~d}$ & $110.35 \mathrm{a}$ \\
MSOY 7908 RR & $87.18 \mathrm{bc}$ & $97.06 \mathrm{~b}$ & $111.41 \mathrm{c}$ & $114.08 \mathrm{c}$ & $118.23 \mathrm{c}$ \\
SYN 3358 RR & $89.93 \mathrm{a}$ & $99.01 \mathrm{a}$ & $115.34 \mathrm{a}$ & $123.93 \mathrm{a}$ & $128.09 \mathrm{a}$ \\
BMX Potência RR & $88.59 \mathrm{a}$ & $99.35 \mathrm{a}$ & $114.77 \mathrm{a}$ & $122.99 \mathrm{a}$ & $127.21 \mathrm{a}$ \\
ND 5909 RR & $85.85 \mathrm{c}$ & $93.69 \mathrm{c}$ & $108.25 \mathrm{~d}$ & $112.63 \mathrm{c}$ & $116.10 \mathrm{c}$ \\
BRS 245 RR & $89.28 \mathrm{ab}$ & $97.26 \mathrm{~b}$ & $112.55 \mathrm{bc}$ & $119.09 \mathrm{~b}$ & $121.77 \mathrm{~b}$ \\
\hline BMX Magna RR & $767 \mathrm{~b}$ & $935 \mathrm{c}$ & $1.553 \mathrm{c}$ & $2.122 \mathrm{c}$ & $2.361 \mathrm{c}$ \\
MSOY 7908 RR & $916 \mathrm{~b}$ & $1,373 \mathrm{~b}$ & $2.025 \mathrm{~b}$ & $2.398 \mathrm{bc}$ & $2.597 \mathrm{~b}$ \\
SYN 3358 RR & $1,049 \mathrm{ab}$ & $1.611 \mathrm{ab}$ & $2.498 \mathrm{a}$ & $3.037 \mathrm{a}$ & $3.333 \mathrm{a}$ \\
BMX Potência RR & $1,311 \mathrm{a}$ & $1.789 \mathrm{a}$ & $2.430 \mathrm{a}$ & $2.953 \mathrm{a}$ & $3.273 \mathrm{a}$ \\
ND 5909 RR & $972 \mathrm{~b}$ & $1.057 \mathrm{c}$ & $2.020 \mathrm{~b}$ & $2.357 \mathrm{bc}$ & $2.410 \mathrm{c}$ \\
BRS 245 RR & $980 \mathrm{~b}$ & $1.058 \mathrm{c}$ & $1.884 \mathrm{~b}$ & $2.512 \mathrm{a}$ & $2.726 \mathrm{~b}$ \\
\hline
\end{tabular}

Averages followed by the same letter in rows do not differ by Tukey's test at $5 \%$ probability.

The effect of doses of NPK on MTG and YIE variables (Figure 5 and 6 , respectively) was linear, reaching the highest values at $400 \mathrm{~kg} \mathrm{ha}^{-1}$ in all cultivars. Perini et al. (2012), Carvalho et al. (2011), Nava et al. (2011), Barbaro et al. (2009),
Broch et al. (2009), Ghosh et al. (2009), Bhattacharyya et al. (2008) and Navaro Junior et al. (2002) observed that increasing doses of NPK provided increments in YIE of soybean, agreeing with the results obtained in this research.

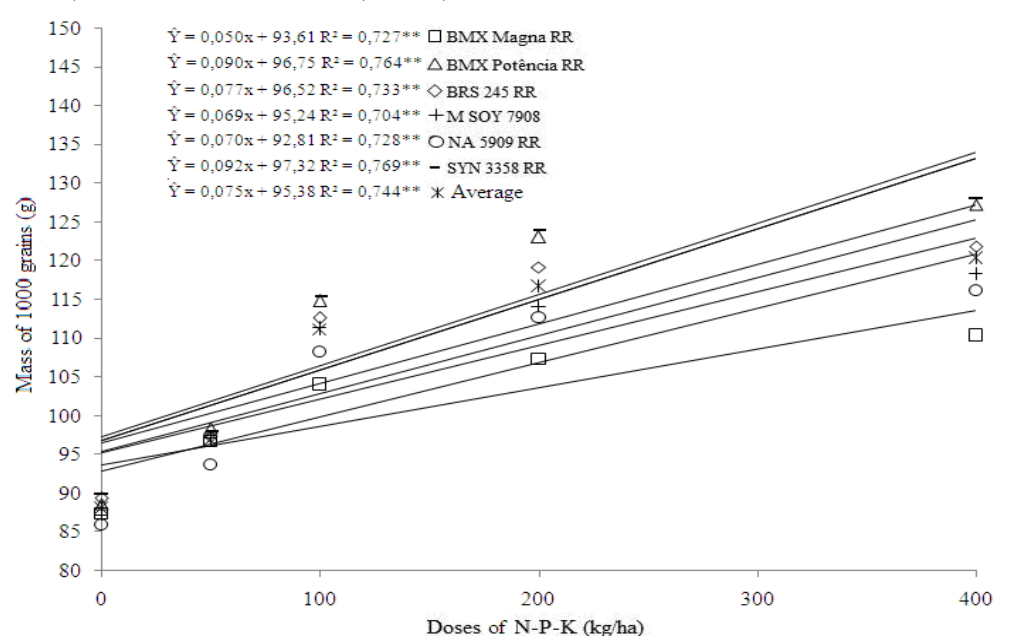

Figure 5. Mass of 1000 grains (MTG) of six soybean cultivars as function of different doses of NPK. Aquidauana, MS, 2012. 


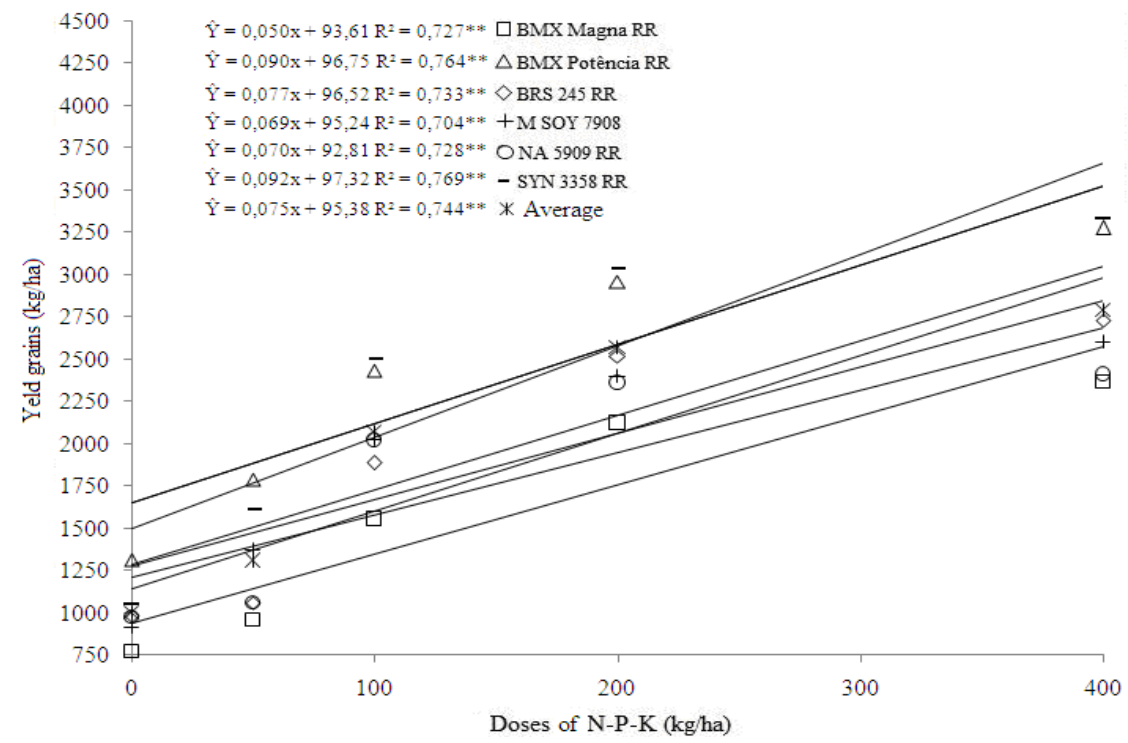

Figure 6. Grain yield (YIE) of six soybean cultivars as function of different doses of NPK. Aquidauana, MS, 2012.

Overall, the results obtained in this research indicate that application of high doses of NPK in soils with low and medium cation exchange capacity provided increase in the agronomic characters of soybean. It is noteworthy that the dose of $400 \mathrm{~kg} \mathrm{ha}^{-1}$ NPK provided the cultivars SYN 3358 RR and BMX Potência RR YG exceeding the national average, which is $2,900 \mathrm{~kg} \mathrm{ha}^{-1}$. It is important to note that the results obtained with this dose provided YG similar to other studies with soybean cultivars developed in this region (TEODORO et al., 2015; TORRES et al., 2015; TORRES et al., 2014). Based on these results, it is recommend the use of these cultivars and base fertilization for integrated crop-livestock in Brazil, especially in the Cerrado (Savanna) region.

\section{CONCLUSIONS}

Increased doses of base fertilizer wich NPK caused a linear increase in all variables in all cultivars.

It is recommended base fertilization at the dose of $400 \mathrm{~kg} \mathrm{ha}^{-1}$ of NPK being recommended for cultivation on straw Brachiaria decumbens pasture degraded.

The cultivars BMX Potência and SYN RR 3358 RR showed higher weight of 1000 grains and, consequently, higher yield grain.

RESUMO: A implantação da cultura da soja sob plantio direto em pastagem degradada vem sendo uma prática trivial, e o uso eficiente e racional de fertilizantes é um fator decisivo para a sua viabilidade econômica. O objetivo foi avaliar o desempenho agronômico de seis cultivares submetidas a doses adubação de base com NPK e cultivadas sobre palhada de Brachiaria decumbens. O experimento foi conduzido na área experimental da Universidade Estadual de Mato Grosso do Sul, Unidade de Aquidauana (UEMS/UUA). O delineamento experimental foi em blocos casualizados em esquema parcelas subdivididas, com quatro repetições. As parcelas foram constituídas de seis cultivares de soja (NA 5909 RR, M SOY 7908 RR, BMX Magna RR, BRS 245 RR, SYN 3358 RR, BMX Potência RR) e as subparcelas por cinco doses de NPK $\left(0,50,100,200\right.$ e $\left.400 \mathrm{~kg} \mathrm{ha}^{-1}\right)$. Foram avaliados a altura da planta, altura da primeira vagem, número de ramificações por planta, massa de 1000 grãos e produtividade de grãos. O aumento das doses de fertilizante causou um incremento linear em todas as variáveis avaliadas em todas cultivares avaliadas, sendo recomendada para pastagens degradadas à adubação de base com $400 \mathrm{~kg} \mathrm{ha}^{-1}$ de NPK. As variedades BMX Potencia RR e SYN 3358 RR apresentaram maior massa de 1000 grãos e, consequentemente, maior produtividade de grãos.

PALAVRAS-CHAVE: Integração lavoura-pecuária. Pastagem degrada. Glycine Max. Plantio direto. 


\section{REFERENCES}

ARAÚJO, W. F.; SAMPAIO, R. A; MEDEIROS, R. D. Resposta de cultivares de soja à adubação fosfatada. Revista Ciência Agronômica, Fortaleza, v. 36, p. 129-134, 2005.

BÁRBARO, I. M.; CENTURION, M. A. P. C.; GAVIOLI, E. A.; GARCIA, D.; SARTI, P.; BÁRBARO JÚNIOR, L .S.; TICELLI, M.; MIGUEL, F. B. Análise de cultivares de soja em resposta à inoculação e aplicação de cobalto e molibdênio. Revista Ceres, Viçosa, v. 56, p. 342-349, 2009.

BHATTACHARYYA, R.; KUNDU, S.; PRAKASH, V.; GUPTA, H. S. Sustainability under combined application of mineral and organic fertilizers in a rainfed soybean-wheat system of the Indian Himalayas. European Journal of Agronomy, Amsterdam, v. 28, n. 01, p. 33-46, 2008.

http://dx.doi.org/10.1016/j.eja.2007.04.006

BROCH, D. L.; NOLLA, A.; QUIQUI, E. M. D.; POSSENTI, J. C. Produtividade da soja influenciada pela aplicação de doses de fertilizante com disco desencontrado e sulcador em um latossolo sob plantio direto. Revista Ciências Exatas e Naturais, Santa Cruz, v. 11, n. 2, p. 256-269, 2009.

CARVALHO, E. R.; REZENDE, P. M.; ANDRADE, M. J. B.; PASSOS, A. M. A.; OLIVEIRA, J. A. Fertilizante mineral e resíduo orgânico sobre características agronômicas da soja e nutrientes no solo. Revista Ciência Agronômica, Fortaleza, v. 42, p. 930-939, 2011. http://dx.doi.org/10.1590/S180666902011000400015

CONAB: Companhia Nacional de Abastecimento. Acompanhamento de safra brasileira: grãos, décimo levantamento, julho 2014.

FERREIRA, D. F. Sisvar: a computer statistical analysis system. Ciência e Agrotecnologia (UFLA), Lavras, v. 35, n. 6, p. 1039-1042, 2011.

GARCIA, C. M. P.; ANDREOTTI, M.; TEIXEIRA FILHO, M. C. M.; LOPES, K. S. M.; BUZETTI, S. Decomposição da palhada de forrageiras em função da adubação nitrogenada após o consórcio com milho e produtividade da soja em sucessão. Bragantia, Campinas, v. 73, n. 2, p.143-152, 2014.

http://dx.doi.org/10.1590/brag.2014.016

GHOSH, P. K.; TRIPATHI, A. K.; BANDYOPADHYAY, K. K. Assessment of nutrient competition and nutrient requirement in soybean/sorghum intercropping system. European Journal of Agronomy, Amsterdam, v. 31, n. 01, p. 43-50, 2009. http://dx.doi.org/10.1016/j.eja.2009.03.002

LUDWIG, M. P.; DUTRA, L. M. C.; LUCCA, O. A.; ZABOT, L.; JAUER, A.; UHRY, D. Populações de plantas na cultura da soja em cultivares convencionais e Roundup Ready ${ }^{\mathrm{TM}}$. Revista Ceres, Viçosa, v. 58, p. 305-313, 2011.

MACEDO, M. C. M. Integração lavoura e pecuária: o estado da arte e inovações tecnológicas. Revista Brasileira de Zootecnia, Viçosa, v. 38, p. 133-146, 2009.

MACHADO, L. A.; VALLE, C. B. Desempenho agronômico de genótipos de capim-braquiária em sucessão à soja. Pesquisa Agropecuária Brasileira, Brasília, v.46, n.11, p.1454-1462, 2011.

MARCOS FILHO, J. Produção de sementes de soja. Campinas: Fundação Cargill, 1986. 86 p.

MAUAD, M.; SILVA, T. L. B.; ALMEIDA NETO, A. I.; ABREU, V. G. Influência da densidade de semeadura sobre características agronômicas na cultura da soja. Revista Agrarian, Dourados, v. 3, p. 175-181, 2010. 
NAVA, I. A.; GONÇALVES JÚNIOR, A. C.; GUERINI, V. L.; NACKE, H.; SCHWANTES, D. A. Efeito agroeconômico de adubos formulados contendo zinco de diferentes marcas comerciais no cultivo da soja em um Latossolo vermelho. Scientia Agraria Paranaensis, Cascavel, v. 10, n. 3, p. 32-44, 2011.

NAVARRO JUNIOR, H. M.; COSTA, J. A. Contribuição relativa dos componentes de rendimento para produção de grãos em soja. Pesquisa Agropecuária Brasileira, Brasília, v. 37, p. 269-274, 2002.

http://dx.doi.org/10.1590/S0100-204X2002000300006

NUNES, A. S.; TIMOSSI, P. C.; PAVANNI, M. C. M. D.; ALVES, P. L. C. A. Brachiaria decumbens management times in soybean under no tillage system. Planta Daninha, Viçosa, v. 27, n. 2, p. 297-302, 2009.

PAULINO, V. T.; SCHUMANN, A. M.; SILVA, S. C.; RASQUINHO, N. M.; SANTOS, K. M. Impactos ambientais da exploração pecuária em sistemas intensivos de pastagens. Informe Agropecuário, Belo Horizonte, v. 33, p. 17-24, 2012.

PERINI, N. S.; FONSECA JUNIOR, L. J.; DESTRO, D.; PRETE, C. E. C. Componentes da produção em cultivares de soja com crescimento determinado e indeterminado. Semina: Ciências Agrárias, Londrina, v. 33, p. 2531-2544, 2012.

RAMBO, L.; COSTA, J. A.; PIRES, J. L. F.; PARCIANELLO, G.; FERREIRA, F. G. Rendimento de grãos da soja em função do arranjo de plantas. Ciência Rural, Santa Maria, v. 33, p. 405-411, 2003.

http://dx.doi.org/10.1590/S0103-84782003000300003

REZENDE, P. M.; GRISC, F.; GOMES, L. L.; TOURINO, M. C.; BOTREL, E. P. Efeito da semeadura a lanço e da população de plantas no rendimento de grãos e outras características da soja. Ciência e Agrotecnologia, Lavras, v. 28, p. 499-504, 2004.

SCHIAVO, J. A.; PEREIRA, M. G.; MIRANDA, L. P. M.; DIAS NETO, A. H.; FONTANA, A. Caracterização e classificação de solos desenvolvidos de arenitos da formação Aquidauana-MS. Revista Brasileira de Ciência do Solo, Viçosa, v. 34, n. 3, p. 881-889, 2010.

TAIZ, L.; ZEIGER, E. Fisiologia vegetal. 5a ed. Porto Alegre: ArtMed, 2013. 954p.

TEODORO, P. E.; RIBEIRO, L. P.; CORREA, C. C. G.; LUZ JUNIOR, R. A. A.; ZANUNCIO, A.;

CAPRISTO, D. P.; TORRES, F. E. Path analysis in soybean genotypes as function of growth habit. Bioscience Journal, Uberlândia, v. 31, p. 794-799, 2015. http://dx.doi.org/10.14393/BJ-v31n1a2015-26094

TORRES, F. E.; DAVID, G. V.; TEODORO, P. E.; RIBEIRO, L. P.; CORREA, C. C. G.; LUZ JUNIOR, R. A. A. Desempenho agronómico e dissimilaridade genética entre genótipos de soja. Revista de Ciências Agrárias, Lisboa, v. 38, p. 112-118, 2015.

TORRES, F. E.; SILVA, E. C.; TEODORO, P. E. Desempenho de genótipos de soja nas condições edafoclimáticas do ecótono Cerrado-Pantanal. Interações (UCDB), Campo Grande, v. 15, p. 71-78, 2014. http://dx.doi.org/10.1590/S1518-70122014000100007 